\title{
The Existence of the Development of Integrated Islamic Education Institutions (SDIT) and Madrasah in Purwodadi Village
}

\author{
Wina Calista \\ STIT NU Sumber Agung O ku T imur, Palembang,Indonesia \\ winacalista21@gmail.com \\ M udiyono \\ ST IT N U Sumber Agung 0 ku T imur, Palembang,Indonesia \\ mudiyono05@gmail.com
}

\begin{abstract}
This research aims to analyze the problem of the development of integrated Islamic elementary schools and madrasah in purwodadi village. The approach used is a descriptive approach to analysis of qualitative data. In addition, the data collection techniques used in the study used observation, interviews and documentation. The result of this study is the problem of the development of Islamic-based school trends (SDIT) that have an impact on madrasah. Purwodadi Village has 1 General Kindergarten and 2 TKIT, elementary school consists of 2 State Elementary Schools and 2 SDIT and M adrasah Ibtida'iyah (MI) only 1. So that the total elementary school age education institution in one village has 4 elementary schools. The development of an Integrated I slamic school in purwodadi village had an impact on madrasah. O ne of the advantages of SDIT has learning programs such as memorization of quran and hadith, sunnah Dhuha prayer before starting learning activities, murojaah, dzuhur prayer before school, Friday almsgiving, and other activities. These activities are then a special consideration for parents in choosing educational institutions for their children. While madrasah does not have an activity program that supports learning such as in SDIT. O ne of the effects is the reduced interest of students who attend madrassas. This is because of the trend of Islamic schools that develop in the village with a variety of learning programs offered.
\end{abstract}

Keywords: Developmental Probematics, Islamic School, Rural 


\section{A. Introduction}

Rural culture as perceived and understood by most people is economically weak, low creativity culturally, low awareness of education but has a strong soul and social attitude. ( $Q$ omar, 2015). The situation and condition of the village in ancient times and today there are still some villages that are still strong with the picture. However, at this time the paradigm about rural areas has undergone a shift in viewpoints that are becoming an advanced and developed village in everything including mindset and education. N ow many village scholars or who are studying in college.

In addition to the growth of scholars from the village coupled with the trend of education based on Islam in the countryside. The dominance of pesantren, madrassas and schools (public) which became the manstream model of educational institutions at the end of the 20th century has shifted along with the trend of Integrated Islamic Schools ( $H$ asan, 2011). Started in the 1990s by mosque activists on itb campus and UI the emergence of education with an Islamic basis is able to attract the attention and interest of the public (Suyatno, 2013).

The development of I slamic educational institutions is currently a trend in the elite to rural communities. This is evidenced by the emergence of Islamic-based schools from early childhood education to top-level education. In the range of 20 years the development of Islamic-based schools around 10,000 schools throughout Indonesia from the level of early to secondary childhood education and continues to grow to date ( $H$ isam, 2012). The development of schools with an Islamic basis has the support of the factor of decentralization of education policies at the provincial and district levels so that each party is more free in establishing and developing Islamic educational institutions. Islamic-based schools are a form of institution that integrates general science with Islamic values contained in an integrative curriculum package. With the stronger position of Islamic Education in the Indonesian education system after experiencing a very long struggle period, of course, the ideal has shown significant results and the goal of Islamic religious education has been achieved, namely physical education, resource education and moral education. To maintain the existence of madrassas and Islamic schools must meet three minimum demands in improving the quality of Madrasah and Islamic schools, namely: making madrassas and Islamic schools as places to foster the spirit or practice of I slamic life, strengthening the existence of madrassas and Islamic schools so that they are equivalent to islamic school systems, madrassas and schools must be able to respond to future demands to anticipate the development of science and technology and the era of globalization ( $H$ uda and Rhoni Rodin 2020) . 
The presence of an Islamic-based school model certainly brings new innovations in the world of education, namely because the curriculum integrates general science with Islamic values. In addition, it is also to strengthen the character education of students through the values of Islam taught. But in the midst of the trend of Islamic-based schools such as SDIT certainly indirectly affect private elementary schools / private madrassas. This is because of the high interest of parents in choosing Islamic-based educational institutions such as SD IT .

Purwodadi Village is one that already has educational institutions such as 2 State Elementary Schools, 1 private MI, and 2 SDIT with a village area that is not so large. The beginning of the growth of Islamic elementary schools in this village received appreciation as well as negative views from the community and village leaders. This can then lead to competition and cases of student dispossession or the fate of private schools in the village. Private schools are considered as grandparent schools that must be ready to compete with modern Islamic-based schools. Based on the preliminary study, an interview with the head of a private madrassa with the initials M r. AM explained that with rural circumstances but having many educational institutions certainly have an impact on private schools because of course something new will attract and interest parents to send their children to modern schools.

Madrasah which is a school that adopts from pesantren education must be able to adapt to the vision of the mission of a modern Islamic-based school. Situations and conditions like this affect the commitment, determination and spirit of parents in putting their children into Islamic schools. This is motivated by parents who begin to be selective in choosing established and modern educational institutions, competent educators, facilities and infrastructure and the vision of the school's mission. So that the development of Islamic-based schools in rural areas is considered as a challenge as well as the progress of Islamic education to be more stable. This requires that private schools / madrasas be able to go hand in hand despite the development of the trend of integrated Islamic schools.

From the preliminary study and discussion above, this paper will analyze more deeply about the problem of the growth and development of Islamic schools in the countryside. Purwodadi village is a village that will be a research location because it has many public education institutions and based on Islam.

The method used in this study is a qualitative method. Qualitative method is a research method used to conduct a study on an object naturally and in this case the researcher as a key instrument ( Sugiyono, 2016). The approach used is a descriptive approach to analysis of qualitative data. In addition, the data collection techniques used in this study used observation, interviews and documentation. (Prastowo, 2011). 
Interview is one of the data collection techniques that are done by holding questions and answer, either directly or indirectly with the data source. The interview technique used in this study is a planned interview but does not use a standard format and sequence (Yusuf, 2007). Therefore, in the implementation of in-depth interviews, the questions that will be presented to the informant cannot be formulated definitively in advance, but they will depend a lot on the ability and experience of the researcher to develop follow-up questions in accordance with the informant's answer. . The study began from June 28, 2021 to July 9, 2021. The informant in this study was the Principal in M adrasah Al Hikmah village of Purwodadi. The purpose of the study in this study was to analyze the problem of developing integrated Islamic elementary schools and madrasas in rural areas precisely in purwodadi village.

\section{B. Discussion}

Islamic education in Indonesia in the history of its support, starting at the time of colony until Indonesia became independent faced various problems and gaps in various aspects, in the form of dichotomy issues of education, curriculum, goals, resources, and management of I slamic education. So Azra said that I slamic education as seen in the drafting of the National Education System Act of 2003, although there are some articles that have not been realized consistently by the government, for example Article 49 paragraph 12 on the education budget (Azyumardi Azra, 1999). When viewed based on the law that the government's attention to Islamic religious education is relevant to the institution has been equated with public schools so that there is no longer any difference between one institution and another Islamic educational institution. 0 ne of the proofs that Islamic Education has received the attention of the government, can be seen from the influence of the idea of reform that develops in the Islamic world and the rise of the Indonesian nation, process by process of general learning included in the madrasah curriculum (N ursyarief, 2014)

The development of Science and Technology in the 21st Century has a significant impact on the world including in the world of education. The development of the world of education is followed by the growth and development of public education institutions to islambased institutions spread throughout Indonesia. The growth of educational institutions that are not only elementary schools (elementary) and madrasah Ibtida'iyah (MI) but now emerged Islamic schools or the dominant one known as integrated Islamic schools (SIT). This school develops itself from the beginning of Kindergarten education (kindergarten) which in Islamic schools is known as Integrated Islamic Kindergarten (TKIT) and Integrated Islamic Elementary School (SDIT). 
In Purwodadi village has 1 General Kindergarten and 2 TKIT, elementary school consists of 2 State Elementary Schools and 2 SDIT and M adrasah Ibtida'iyah ( MI) only 1. So that the total elementary school age education institution in one village has 4 elementary schools. From the data it is known that the significant growth of educational institutions in rural size. If the school al ready has a license as a public school would have become the auspices of the government. Unlike private schools that must continue to strive to improve quality and quantity. This aims to remain an attraction in itself, especially for parents who will determine educational institutions for their children.

SDIT is an Islamic-based school that certainly has a slightly different learning pattern from public schools or madrasas. As in some SDIT requires its students to memorize quranic verses or hadiths, dhuha prayers or sholah Dzuhur in school. These activities are then a special consideration for parents in choosing educational institutions for their children. If viewed from the positive side, the growth and development of modern schools or schools is a form of educational renewal. In the sense that education is increasingly adjusting to the times and the demands and needs of learners in the 21st century.

The development of the insights of the current village community is experiencing a significant increase. M otivated by the number of village undergraduate graduates, community insights are also widely developed with the presence of media or technology that quickly accesses information online. The development of the mindset of the village community certainly has positive and negative thoughts towards Islamic educational institutions. The development of broader insights led to the growth of optimism of parents in choosing Islamic educational institutions for their children. But with broad insights, parents also selectively choose educational institutions that have a definite mission vision, complete facilities, good learning programs, competent educators and infrastructure facilities that support the learning process (Q omar, Strategi Pendidikan Islam, 2013).

So the growth of SDIT educational institutions in rural communities is seen as a response in the renewal and realignment of Islamic educational institutions to be more religious. Amid the development of integrated Islamic school trends, there are madrasas that have existed since the 1990s. M adrasah whose basis is to adopt from pesantren education has since ancient times developed education with the basis of I slamic education. In the midst of the development of integrated Islamic schools, now madrassas still exist as Islamic educational institutions in rural communities.

M I Al H ikmah in Purwodadi village became the only madrassa that is still active today. It can be said that al-Hikmah madrassa became the oldest Islamic educational institution in 
purwodadi village. Amid the development of the trend of Integrated Islamic schools in the village of Purwodadi M adrasah Al H ikmah is required to be able to compete and maintain the khualitas of his education. Of course this aims to make madrasah as an Islamic educational institution that still has the trust in the community.

Based on the results of the interview of the head of the madrasah revealed that al$\mathrm{Hikmah}$ madrasah still survives to this day because most people still consider that this madrasah as the school of kyai in the village because the establishment of this madrasah was the result of the struggle of the kyai so that there are still many people who still entrust Al $H$ ikmah as an educational destination for their grandchildren. Although the students are not as many as they used to be because many new schools exist in purwodadi village.

O ne of the impacts of the growth and development of Islamic educational institutions in the village is competition and the capture of learners. There are several causes that can cause high or low interest in choosing educational institutions including public perception, management or the level of public trust. If the cause is due to misperception then an institution needs to socialize and if the cause is a management problem then the manager should rearrange it in accordance with procedures and principles. And if the cause is a decrease in the level of community trust, then all components of the school from principals / madrasas to teachers must jointly build community trust. (Q omar, Strategi Pendidikan Islam, 2013).

Some things that can be done to build academic and non-academic achievement of madrasah, socialize madrassa graduates who are accepted in good educational institutions, financial management, provide good services and others. Where these efforts can be done by madrasas amid the development of SDIT in the countryside. So that the interest of parents to send their children to school in madrasas remains high. $0 \mathrm{n}$ the other hand, madrassas are also required to be active in following the development of the world of education today. If these efforts are difficult to do by madrasas then all of that will provide good momentum for the entry of new learners into the madrassa. This is the new hope of madrassas so as not to be left behind from other institutions including Islamic educational institutions in order to occur balance between institutions.

In addition, if we observe together that one of the tricks carried out by SDIT in maintaining existence in society is to activate existence in publications on social media. Where all learning activities and programs in schools are always in publication to be reached by the wider community in introducing or promoting their schools. Nursikin in his research concluded that establishing the existence of M adrasahs and Islamic schools to meet three minimum demands in improving the quality of madrassas and Islamic schools, namely: making 
madrassas and schools, Islam as a place to foster the spirit or practice of Islamic life, strengthening the existence of madrassas and Islamic schools so that equivalent to the islamic school system, madrassas and schools must be able to respond to future demands to anticipate the development of islamic life. science and globalization.

\section{Conclusion}

Based on the results of an analysis on the problem of the development of integrated Islamic elementary schools and madrasas in rural areas it can be concluded that Purwodadi village has 1 General Kindergarten and 2 TKIT, elementary school consists of 2 State Elementary Schools and 2 SDIT and Madrasah Ibtidaliyah (MI) only 1. So that the total elementary school age education institution in one village has 4 elementary schools. The development of an Integrated Islamic school in purwodadi village had an impact on madrassas. O ne of the advantages of SDIT has learning programs such as memorization of quran and hadith, sunnah D huha prayer before starting learning activities, murojaah, dzhur prayer before school, F riday almsgiving, and other activities. These activities are then a special consideration for parents in choosing educational institutions for their children. While madrasah does not have an activity program that supports learning such as in SDIT. O ne of the effects is the reduced interest of students who attend madrassas. This is because of the trend of Islamic schools that develop in the village with a variety of learning programs offered.

\section{References}

Abdulyani. (2007) . Sosiaologi: skematika, teori dan terapan. Jakarta: PT Bumi AK sara.

Arikunto, S. (2013). Prosedur Penelitian (Suatu Pendekatan Praktik). Jakarta: Rineka Cipta.

Danim, S. (2002). M enjadi Peneliti Kualitatif Rancangan M etodologi, Prestasi dan Publikasi $\mathrm{H}$ asil penelitian untuk M ahasiswa dan Penelitian Pemula Bidang IImu Sosial, Pendidikan dan H umaniora. Bandung: Remaja Rosdakarya.

Djamarah, S. B. ( 2011). Psikologi Belajar. Jakarta: Rineka Cipta.

H antono, D . (2018). Aspek Prilaku M anusia Sebagai M akhluk Individu dan Sosial pada Ruang Terbuka Publik. N ational Academik Journal Of Architecture, Vol 2 No 2.

Hasan, N. (2011). Islamizing School and New Trend in Formal Education Institution In Indonesia. Rajartanam S

Huda, Miftahul, and Rhoni Rodin. 2020. "Perkembangan Pendidikan Islam Di Indonesia Dan U paya Penguatannya D alam Sistem Pendidikan Nasiona.” Journal of Islamic Education Research 1(2). https:/ / jier.iain-jember.ac.id/ index.php/ jier/ article/ view/ 24/ 13. 
M ahmud. (2015). Bandung: PT Remaja Rosdakarya.

Mahmud. (2015). In Pendidikan Lingkungan Sosial Budaya. Bandung: PT Remaja Rosdakarya.

N ani, S. Y. (2010) . Perkembangan Peserta D idik. Jakarta: Kencana Prenada M edia G roub.

Nursikin, Muhammad. 2018. "Eksistensi Madrasah Dan Sekolah Islam Sebagai Lembaga Pendidikan Islam Dalam Sistem Pendidikan N asional: Studi Kasus Di M AN Yogyakarta III Dan SMA Muhammdiyah 1 Yogyakarta." Jurnal Istawa: Jurnal Pendidikan Islam 3(1): 2018.

Prastowo, A. (2011). M emahami M etode-M etode Penelitian (Suatu Tinjauan Teoritis dan Praktis) . Yogyakarta: Ar-Ruzz M edia.

Q omar, M . (2013) . Strategi Pendidikan I slam. Jakarta: Erlangga.

Q omar, M . (2015) . Strategi Pendidikan Islam. Bandung: Erlangga.

Rohman, J. S. (2009). Sosiologi. Jakarta: Intan Prawira.

Santoso, S. (2004) . Dinamika K elompok. Jakarta: Bumi A ksara.

Soekamto, S. (2006). Sosiologi Suatu Pengantar. Jakarta: PT Raja G rafindo Persada.

Sugiyono. (2016). Metode Penelitian Pendidikan (Pendekatan Kuantitatif, Kualitatif dan $R \& D)$. Bandung: Alfabeta.

Suyatno. (2013). Sekolah Islam T erpadu .JPI.

Uno, H . B. ( 2014) . Teori M otivasi dan Pengukurannya . Jakarta: PT Bumi Aksara. 